\title{
HOLISTIC APPROACH TO THE SUSTAINABLE COMMERCIAL PROPERTY BUSINESS: ANALYSIS OF THE MAIN EXISTING SUSTAINABILITY CERTIFICATIONS
}

\author{
Aliane VIEIRA DE CASTRO D*, Gema RAMÍREZ PACHECO (D), Fco. Javier NEILA GONZÁLEZ \\ Department of Construction and Building Technology, Technical University of Madrid (UPM), Madrid, Spain
}

Received 10 June 2019; accepted 24 November 2019

\begin{abstract}
Sustainability is no longer a new concept. However, applying, measuring and reporting on the sustainability initiative is still a somewhat confused and subjective issue. There is a huge variety of sustainability guidelines and green building schemes of differing natures, meanings and wordings. Despite this, there is no one guideline providing a crossreference between corporate social responsibility and green building performance to help the commercial property market completely incorporate sustainability into their activities. Therefore, this paper intends to link sustainability, real estate environmental, social, and governance (ESG) and sustainable building in order to help companies internalise this concept in all areas of their operations aligning it with their strategic planning. From desk-based research, this proposal examines and compares key aspects of the main schemes in existence, which are currently evolving in the definition, assessment and report of sustainability at the corporate and built environment level. This approach provides key information to help professionals get a better understanding of the specific changes which sustainability brings about in their corporate process, strategies, investment decisions, daily business operations as well as their property management. The insights presented here can support real estate companies to develop comprehensive communication flows and tools for the measurement and disclosure of sustainability data.
\end{abstract}

Keywords: sustainable development, real estate, green building certification, corporate social responsibility, commercial property, decision support model.

\section{Introduction}

Currently, many commercial property investors, owners and corporate tenants are coming to recognize the importance of including environmental, social, and governance (ESG) risks into their decision-making processes (Reed et al., 2009; Deloitte, 2014; S\&P Dow Jones Indices LLC, 2019; RICS, 2015). This has been stimulating real estate companies to incorporate sustainability dimensions into their corporate policies and business activities. Nonetheless, creating value from these criteria is still somewhat confused and subjective. There is a huge variety of sustainability definitions that change over time and between countries (Warren-Myers, 2012; RICS, 2013). Furthermore, there is no one guideline providing a cross-reference between corporate social responsibility (CSR) and green building performance.

Commercial property is a multifaceted business, which connects investment strategies to building operations and stakeholders have different interests and concerns
(UNEP FI, 2014). Therefore, stakeholders commonly have different perception about this concept and cannot determine the true sustainable performance and quality of a sustainable real estate business (RICS, 2013; Ho et al., 2005). They generally do not communicate directly with each other, focusing only on the sustainable subjects affecting their specific stage of the building's life cycle (i.e. planning, construction, occupancy). For that reason, landlords, developers and managers have more clear information about the suppliers ESG practices and the building efficiency than prospective tenants and buyers (Fuerst et al., 2012; Cox et al., 2013; RICS, 2015). As well as this, looking into the sustainable performance of a property company, the lack of understanding over a single sustainability model by the directors and managers can lead to the incorrect planning of business strategies. It makes integrating the sustainability dimensions into project planning, construction and building operation difficult.

Considering these issues, the property market suffers from some information failures and uncertainty regarding

*Corresponding author. E-mail: alianevdec@gmail.com 
sustainable buildings (Cox et al., 2013). The lack of transparency and the difficult to providing clear data, as well as an interconnected information flow can lead to inefficient transactions and under-performance of the building (Fuerst et al., 2012; Ho et al., 2005). Thus, in order to create one sustainable identity and lessen the problem of information asymmetry, stakeholders have seeking to certify their properties with some sort of green building label (e.g. LEED and BREEAM). Nonetheless, these certifications only offer a quick reference point and the absence of one does not indicate that a building is not sustainable or the organization is not socially responsible (Reed et al., 2009; RICS, 2013). Besides, sustainable building certifications usually focus more on environmental issues (Mahmoud et al., 2019; Atanda, 2019). The balance between social, environmental and economic strategies appears to be a matter of secondary importance (Vieira de Castro et al., 2014).

Carrying this issue further, this paper intends to create a holistic approach, which sets out the social, economic and environmental core aspects of the sustainable real estate business. This proposal provides key information to help professionals get a better understanding of the particular changes which sustainability can bring to their corporate strategies, investment decisions, daily operations as well as their property management. The insights presented here can support real estate companies in developing comprehensive communication flows and tools for the measurement and disclosure of sustainability data. For this, the study examines and compares key aspects of the main existing schemes, which are currently evolving in the definition, assessment and reporting of sustainability at the corporate and built environment level. Thus, this study was developed from desk-based research that uses international standards, sustainability guidelines, green rating bodies as well as the gap in connecting the triple bottom line to the commercial property industry.

Furthermore, this analysis is of particular interest to professionals that are actively involved in the decisionmaking process in the main property business activities, such as the board of directors and managers. Nonetheless, it is also useful for commercial property investment and management firms as well as other professionals and researchers for whom real estate is their core business. Although it was established focusing on real estate companies, whose core business is the development and management of non-residential rental properties (e.g. shopping centres, offices buildings), it can also be adapted for any building type.

This paper presents the following structure according to the research methodology: Section one classifies and groups the main existing corporate sustainability guidelines and green building certification schemes that are currently evolving in the sector worldwide. Then, section two exposes a comparative analysis that highlights which are the core premises needed to understand the concept of sustainability. After that, section three explains in de- tail the fundamental features which completely define the sustainable commercial property business. Thus, in order to create a holistic view, this approach encompasses all commercial property business activity levels i.e. governance level, business/portfolio management level and single building level. Finally, the concluding section provides the main outcomes of the paper and proposes some points for further discussion.

\section{Classification of the main existing sustainability guidelines and green building certifications used by the commercial property market}

The set of references scrutinised in this proposal has been selected from the existing guidelines, international standards, frameworks and ratings bodies, which are currently committed to defining and assessing sustainability at the corporate and built environment level, i.e. documents that describes ESG and sustainable drivers, metrics and systems for evaluating companies' non-financial performance at different administrative levels and real estate corporate functions such as the building's development and management (Figure 1). Furthermore, it is important to highlight that the wide range of organisations involved in this issue includes international standardization institutions, ratings systems, investor platforms, benchmarking and professional associations, whose intentions differ according to their nature (Reed et al., 2009; Bernet et al., 2010; DíazLopez et al., 2019).

In order to facilitate the comparison between the sustainability premises defined by each guideline and certification, the study classifies these documents according to their object of analysis and scope of applicability (see Figure 1). Thus, firstly, they are grouped in two main blocks:

- Business dimension: This includes schemes and guidelines that help companies and organizations to establish CSR processes, measure their performance, manage shifts forward in operations more sustainably and report the impacts to their stakeholders. Usually, these documents are used to enable a sustainable financial market by improving the credibility of the corporate information on sustainability for investors and others stakeholders. They are also connected to the processes that are used to define corporate strategy, business management, as well as asset and portfolio investment.

- Building dimension: This block encompasses ratings bodies and international standards, which focus on establishing a set of references and indicators for assessing the buildings' life cycle sustainability performance (design, planning, construction, operation and maintenance, refurbishment and demolition). These documents highlight the aspects of building that have an impact on protected areas with regard to the sustainability dimensions (i.e. social, economic environment). 


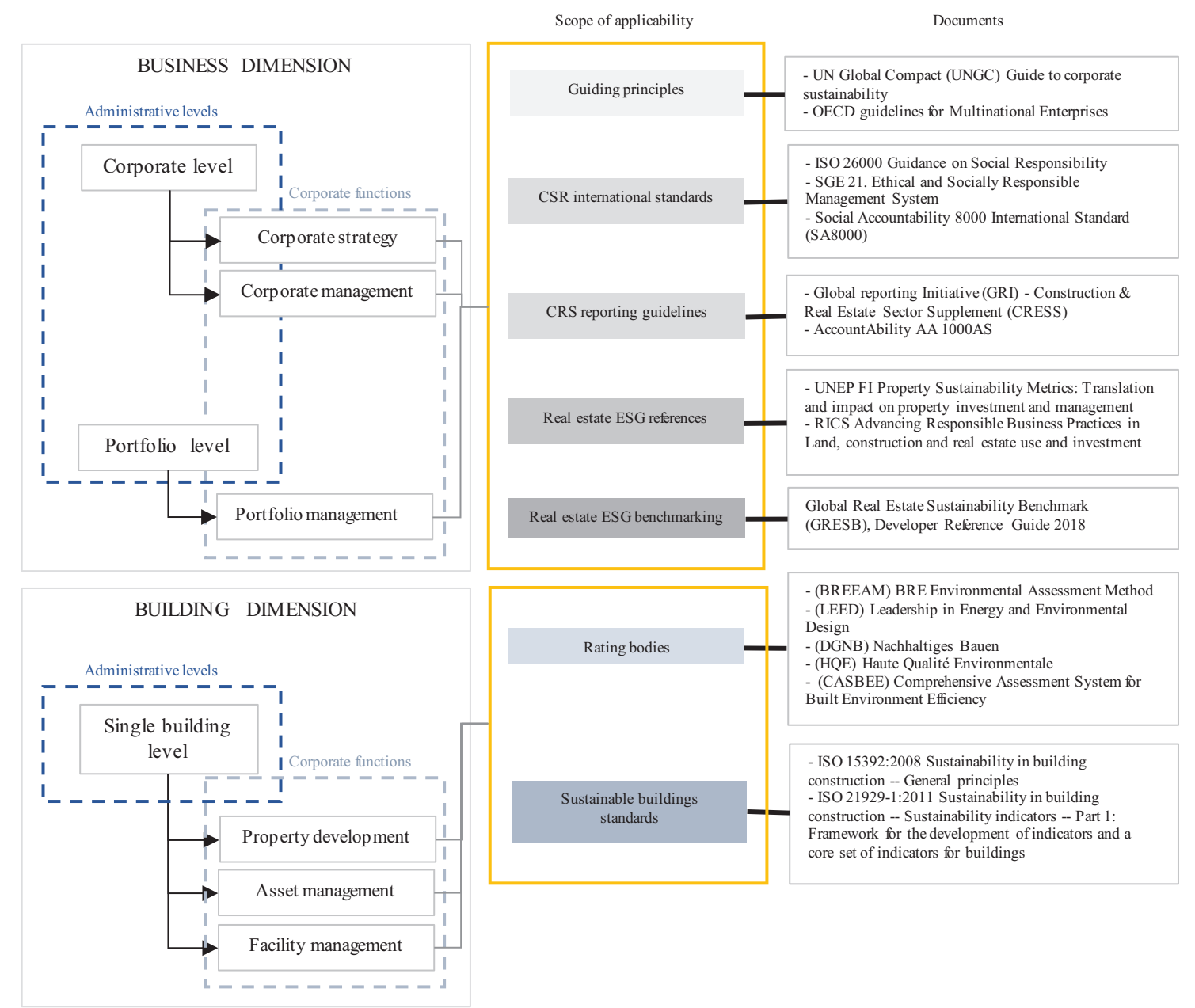

Figure 1. The connection between the administrative levels, corporate functions and the classification of the main documents used by each level (source: elaborated by the authors)

Following on, with regard to the scope of applicability, the documents examined are divided into the following subgroups:

- The business dimension:

1. Guiding principles: These encompass the main documents formulated by International institutions focusing on development and promote principles and policies to improve corporate social responsibility (CSR) worldwide. These documents comprise a number of social, economic and environment recommendations in order for companies to meet their responsibilities on the fundamental issues regarding human rights, labour, environment, transparency, fair business and anti-corruption.

2. CSR international standards: This includes documents that provide guidance, references and Key performance indicators (KPIs) to help businesses and organizations put corporate CSR principles into effect, monitoring their performance and driving the due diligence process.

3. CSR reporting guidelines: This subgroup encompasses guidelines that support companies in communicating their impact on critical sustainability issues in order to link responsible business practices to financial performance.

4. Real estate ESG guidelines: These guidelines focus on providing stakeholders with a better understanding of sustainability measures and practices needed to support the integration of ESG and environmental risks into the real estate businesses, such as property investment and portfolio management.

5. Real estate benchmarking: This block includes an assessment system for measuring the sustainable performance of property companies and real estate funds. These platforms provide investors with actionable information and tools to monitor and manage the ESG risks and opportunities involved in their real estate investments.

- The building dimension:

1. Ratings bodies: These are ratings systems that aim to examine how sustainable a building is in accordance with their own social, economic and environmental parameters. In addition, these schemes provide independent third-party certification of a building's sustainability performance. 
2. Sustainable buildings standards: These include voluntary international standards used for the planning and construction of buildings under environmental premises.

From this perspective, this classification helps develop a deep analysis for understanding the most significant sustainability features for the development of each commercial property business activity. It generates a complete view of the social, economic and environmental dimensions of sustainability and the connections between the applications of each document used by the market. Additionally, the set of documents provides information to allow for a holistic view of the activities and changes made, which is indispensable if a company is to fully incorporate the dimension of sustainability into their strategies and daily operations. Furthermore, this organization can create a practical overview that reduces the degree of confusion surrounding the application of these models.

\section{Comparative analysis for establishing the comprehensive features of the sustainable commercial property}

\subsection{Analysis of the sustainability documents used by the commercial property at business level}

Frequently, the guiding principles (CSR international standards as well as the CSR reporting guidelines analysed) have generic specifications which can be adopted by all sorts of organizations in any economic sector. The Global Reporting Initiative (GRI) is the only one which provides a supplementary document - Construction and Real Estate Sector Supplement (CRESS) - with information specific to the real estate sector activities. Besides, these instruments are of a voluntary nature and in many places worldwide, their issues are applicable under local laws.

With regard to the guiding principles, they are considered the backbone for developing many CSR reporting guidelines and standards that aim to support companies' efforts in implementing, monitoring and reporting sustainable development goals (SDGs) and responsible business conduct in their operations. They outline the foremost principles for an organization to follow in reaching a principled approach to doing business (OECD, 2011; UNGC, 2014). The similarity between these instruments is due to the fact that they share a common normative base. Their values focus on the same declarations and principles such as the Universal Declaration of Human Rights, the International Labour Organization's Declaration on Fundamental Principles and Rights at Work and the Rio Declaration on Environment and Development. Nonetheless, they mainly differ in respect to their level of detail and priority setting practices.

Looking into the International standards and reporting guidelines, many instruments have more than one function, such as the Global Reporting Initiative (GRI), which provides drivers for reporting and setting key indicators to monitor company operations. However, these instruments can be complementary to each other. Therefore, in order to avoid information, overlap when using two or more instruments, the commercial property company should firstly examine their subject, issue definitions and wording to decide which of them are appropriate for identifying their sustainability impacts and for reporting their sustainability behaviour.

From this aspect, ISO 26000 Guidance on Social Responsibility is perhaps the most complete guideline to help commercial property firms in incorporating sustainability into their operations. It offers an in detail guide to sustainability principles as well as a guidance on implementation (Hemphill, 2013). In addition, The Global Reporting Initiative (GRI) supplements it by providing information on reporting many of their issues. Furthermore, GRI is the only reporting guideline that includes specific recommendations for developing non-financial reports and a guide for its application. On the other hand, the AA1000 series of standards could be consolidated as a reference for the validation of reports, as it focuses not only on reporting, but also on the evaluation and assurance of the process.

Looking into the structure of the aforementioned schemes, they include a wide range of similar topics, but specific terms vary considerably. Nonetheless, regardless of their core subject, they have many common premises that can be grouped into six main social responsibility elements: Human rights, labour, environment protection, fair business, consumer rights, community development (UNGC, 2010; ISO, 2017). The Figure 2 shows a scheme that establishes a link between the topics analysed in the main documents and these elements.

In addition, it is important to highlight that these instruments are used as a basis for the creation of other tools focused on assessing the implementation of CSR into business activity. Therefore, understanding their functions is fundamental for the creation of reliable comparative data sets. That is to say, KPIs and indexes used by companies and investors to improve the quality of their activities or to invest responsibly must be connected to solid standardized information in all real estate sector companies.

Bearing in mind the importance of translating the aforementioned sustainability premises into the context of real estate, the instruments grouped together in Real estate ESG references and Real estate ESG benchmarking, address fundamental practices in incorporating sustainability into real estate activities. Their approach provides recommendations and frameworks for helping real estate stakeholders monitor the triple bottom line in the building life cycle and in their investment decision making. In addition, they describe best practices in the building, which commonly are based on some sort of sustainable building rating bodies (see section 2.2 of this paper). Nonetheless, they focus on different documents and have different approaches for each area of application.

In fact, the real estate sector is wide-reaching and includes a variety of owner strategies, tenants and circumstances which directly affect their business' sustainability 


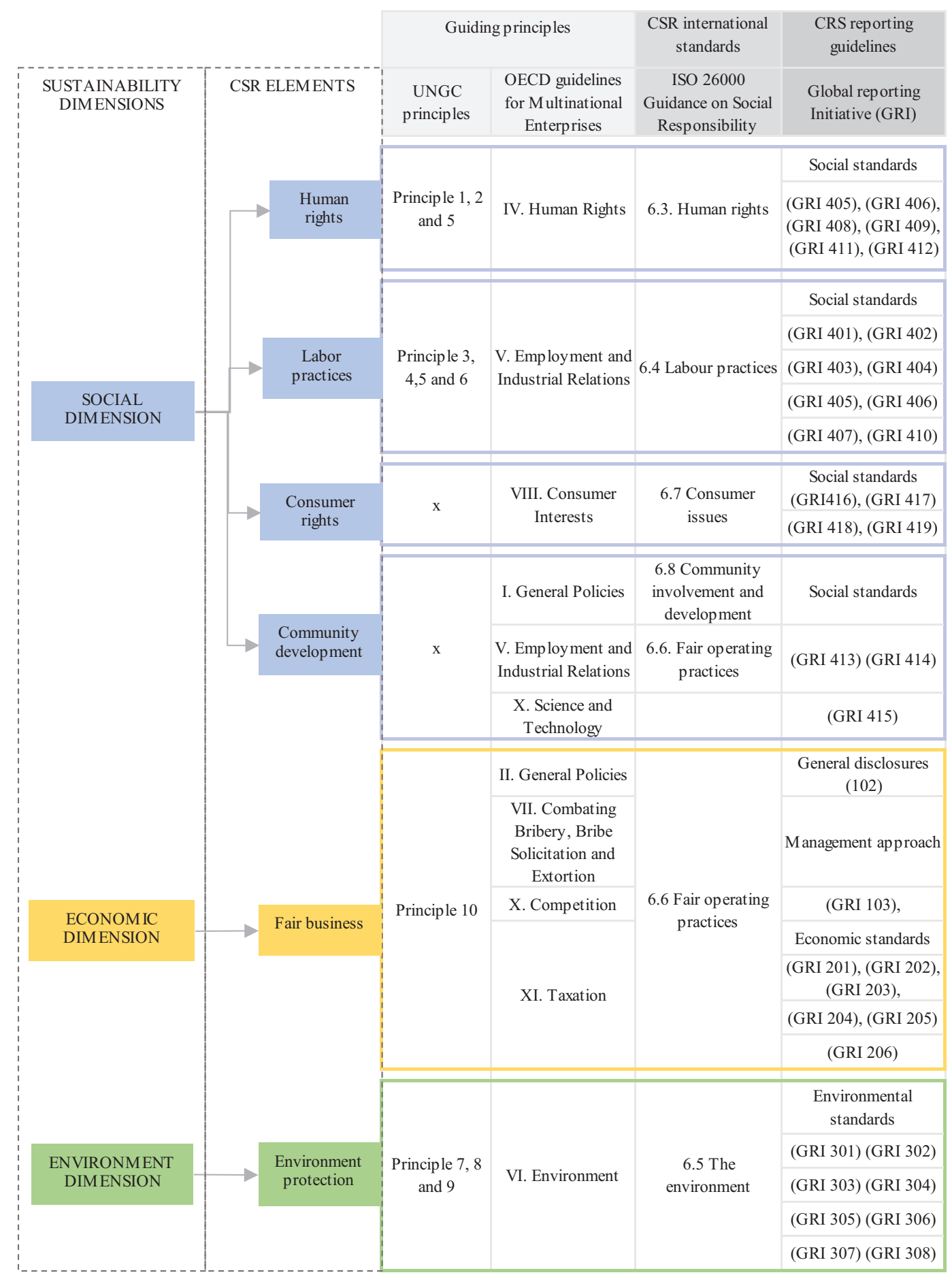

Figure 2. Link between CSR elements and topics of main instruments analysed (source: elaborated by the authors)

performance (UNEP FI, 2014; GRESB, 2018). Due to the broad range of generic topics defined by these documents, they can be used as a quick reference point for companies adapting the information to their own business. In addition, they can help organizations develop their own sustainable management tools. They can also be a starting point for a shift toward new business practices and innovation in the commercial property sector. To conclude this section, it is important point out that CSR is an all-encompassing concept and the commercial property company should analyse each core premise to determine whether it is relevant for their activity and what the priority is for sustainable action for their business to become sustainable. 


\subsection{Analysis of the sustainability schemes used at building environment level}

Sustainable building standards and ratings bodies are instruments which focus on determining the environmental performance of a building. However, ISO 15392:2008 and ISO 21929-1:2011 (ISO, 2011) are systems which aim to establish principles for incorporating sustainability into the decision-making process in the planning, design, construction, management and deconstruction of a building. The first one sets key drivers for implementing the concept of sustainable development in the building's life cycle, as well as other types of construction (ISO, 2008). The second international standard provides a set of the main indicators to be taken into account in the development of measures for assessing the sustainability performance of new or existing buildings. Both standards give sustainability equal importance. They also take into account some principles and procedures set out in the guidance on social responsibility ISO 26000, the GRI sustainability reporting guidelines, as well as the sustainable development principles determined by the United Nations (UN) Commission on Sustainable Development (CSD).

On the other hand, ratings bodies are green certification systems which provide third-party checks on how environmentally sustainable the building is according to their own assessments schemes. Since the 1970s, the interest in the assessment of building's environmental performance has induced intense research with special emphasis on evaluate the built environment's energy efficiency (Díaz-Lopez et al., 2019). Nonetheless, the era of the rating bodies commenced in 1990 with the development of BREEAM by the British Research Establishment before the sustainable development's concept entered into the agenda of international policies with the Rio Conference (Reed et al., 2009; Berardi, 2012). After that, the French system HQE was developed, followed by the U.S. LEED in 2000. According to Reed et al. (2009), the evolution of the certifications worldwide is largely based on these initial rating systems, which are widely spreading rating system. Only in the last two decades, the gradually increase in global awareness on the environmental impacts of the buildings' construction, use and disposal, has been inducing many countries to develop rating systems, which cover sustainable criteria for the whole buildings' life cycle.

Therefore, there is currently an increasing number of certifications, which has been created to assess the sustainability performance of many building's type or the different stages of the building life cycle (Díaz-Lopez et al., 2019; Reed et al., 2009; Mahmoud et al., 2019; Berardi, 2012; Vierra, 2011; Shan \& Hwang, 2018). Besides, the main purpose for the creation of these certifications is the need to improve local knowledge and transparency about the way to implement and measure the outcomes and impacts of green strategies in their building stock (Reed et al., 2009; Vierra, 2011; Benani et al., 2013).
Despite this, certifications score only enable to compare buildings with the same certification (Warren-Myers, 2012). These rating systems differ vastly in scope, wording, topics structures, categories and the weight that each criterion has for scoring. Moreover, the technical criteria in each one includes procedures that are in line with local building regulations (Reed et al., 2009; Banani et al., 2013; Mahmoud et al., 2019; Díaz-Lopez et al., 2019). It occurs due to some specific factors, which vary between countries such as climatic conditions, type of building stock, geographical features, government policies and regulations, historical characteristics, culture value and public awareness (Reed et al., 2009; Benani et al., 2013; Shan \& Hwang, 2018; Mahmoud et al., 2019). As a result, from the perception of real estate investors, whom acquire properties oversea, the lack of unified attributes difficult the comparison of the sustainability performance of their buildings (Dixon et al., 2008; Reed et al., 2009; Mahmoud et al., 2019).

The use of these certification is more common among corporate buildings that may appeal to public sector occupiers or companies (RICS, 2013). It may be explained by the fact that locating their activities in a certified property may affect their corporate reputation mainly among international investors and non-profits (Eichholtz et al., 2010). Hence, real estate investors and developers are advised to undertake a specific analysis to identify which certification is more appropriate for attaining their goals, considering the local regulations, marketability and their sustainable business strategies.

In parallel, it is important highlight that, although the recent review of many certifications (e.g. BREEAM, DGNB, LEED) expresses their standards' relationship with the seventeen Sustainable Development Goals (SDGs) driven by the UN (BREEAM, 2018; LEED, 2018; DGNB, 2018), the ratings body spotlight is yet to have an impact on the building environment. They have a relatively strong emphasis on the building strategies used to increase energy efficiency, reduce resource use and improve the indoor environment quality. The perception of social and economic sustainability such as equality and economic prosperity is still vague (Berardi, 2012; Doan et al., 2017; Atanda, 2019).

According to ISO 21929-1, these features are some of the main building aspects that affect core areas of protection relevant in the assessment of how the built environment contributes to sustainable development. These core areas of protection are ecosystem, natural resources (environment pillar); social equity, cultural heritage, health and well-being (social pillar); economic prosperity and economic capital (economic pillar).

By comparing the contents, wording and subject of these certifications, Figure 3 shows a scheme that arrange the ratings bodies' indicators according to these core areas of protection.

Based on this approach, the certification DGNB can be seen as the only ratings tool to determine an outstanding 


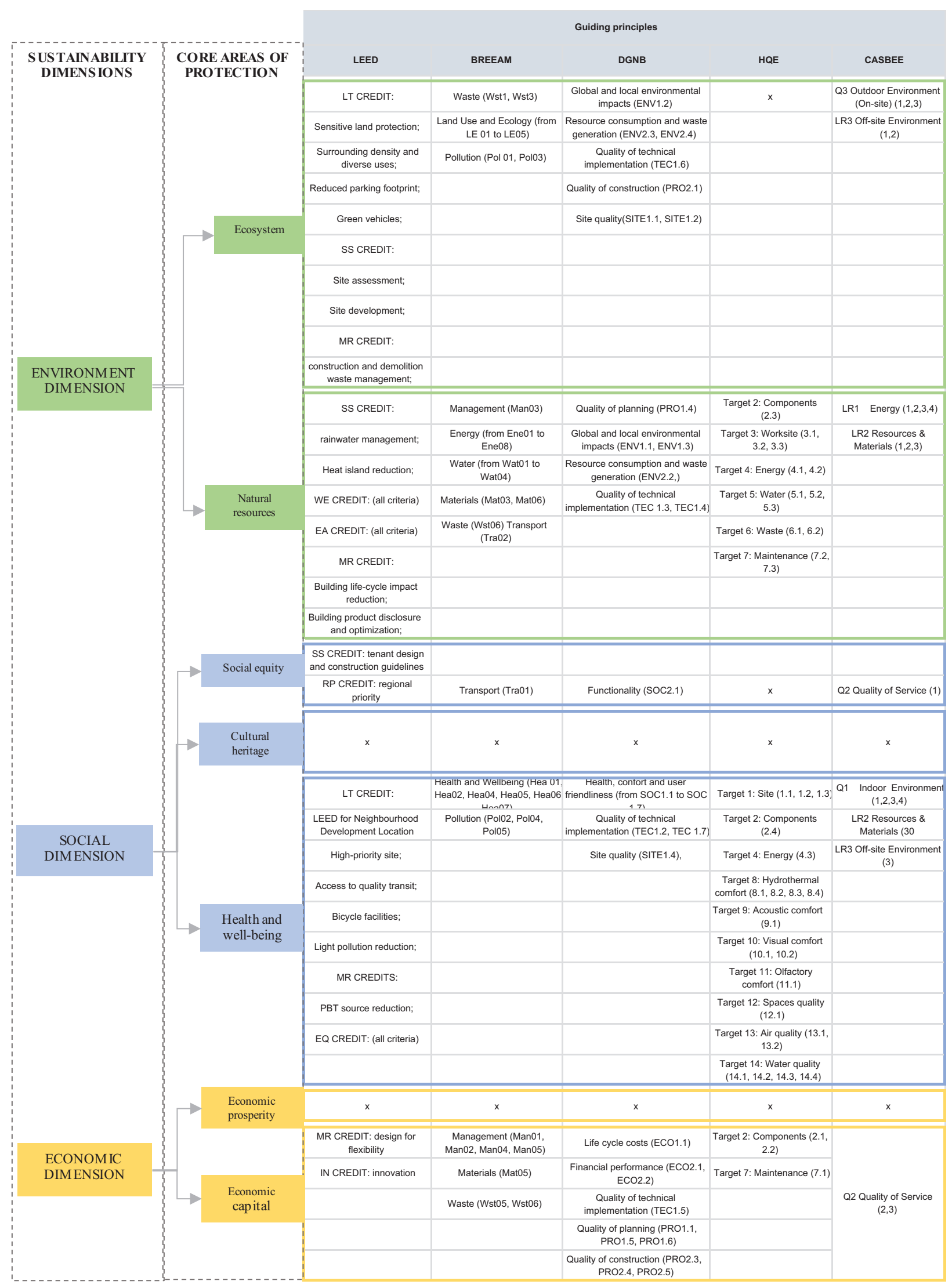

Figure 3. Scheme of the rating bodies' criteria in accordance with the ISO 21929-1 core premises and the sustainability dimensions (source: elaborated by the authors) 
commitment to meeting the balance between all the sustainability aspects in the built environment. The indicators that cover the environmental, economic and socio-cultural credits have similar weight and importance. Nonetheless, BREEAM, LEED and CASBEE give more attention to the subjects that have a primary influence on the environmental dimension. CASBEE merely evaluates the improvement of indoor and outdoor environment quality, as well as the reduction of environment loads such as energy, resources and materials (CASBEE, 2011). In parallel, BREEAM and LEED focus especially on the design features connected with the energy demand, low carbon emissions, materials, land use and transport.

The socially sustainable dimension is of secondary importance in their assessment scheme. They specifically observe the building characteristics that directly affect the comfort, health and wellbeing of the occupants. HQE is the only certification to award the aspects of health and wellbeing with more credit points than the core protection areas of the environment pillar (HQE, 2018). However, the comfort criteria are associated with the building features that indirectly influence the natural resources or ecosystem. Furthermore, in the DGNB and BREEAM schemes, social equality only includes strategies for building in accessibility. In this section, LEED also includes regional priority criteria to encourage stakeholders to achieve credits according to geographically specific environmental, social equality and public health priorities (LEED, 2018).

Concerning the economic pillar, the life cycle cost (LCC), flexibility and adaptability of the building are the main issues covered by the green certifications. The DGNB scheme also provides a criterion to evaluate de commercial viability of the building. A built environment with good, long-term, commercial viability increases not only profit, but also the safety of the local community, its market value and local resource conservation. It is important to point out that the economic sustainability pillar carries the lowest weight for BREEAM, LEED, HQE and CASBEE.

To summarize, it is important observe that there is a complex interrelation between the pillars of sustainable development, whereby one building aspect primarily affects a particular core for sustainable protection and has a potential indirect impact on one or more areas of protection. Developing and managing sustainable buildings require thinking holistically. Furthermore, the commercial property sector has a strong socio-economic and cultural character that differs from region to region. According to ISO 21929 , the sustainability strategies should be considered locally and reflect the context, priorities and needs, not only in the built environment, but also in the social environment. Nonetheless, socio-economic topics are still a matter of secondary importance for the green building assessment. Therefore, it is impossible to determine the complete sustainability impact that a planning, construction and building operation produces in the context of a given local community, as well as how the real estate asset contributes to its socio-economic progress.

\section{The holistic approach for the sustainable commercial property business}

The comparative analysis of CSR and sustainable building instruments show that a wide range of sustainability aspects are associated with corporate management. These not only influence a commercial property firm's strategic planning, but also their daily operations, the building development process and asset management. These functions are part of a multifaceted operational scheme involving the different hierarchical levels within the organisation. They produce a complex interrelated information flow, which according to UNEP FI (2014) needs to be systematically managed to incorporate sustainable considerations in the day-to-day business routine and decision-making processes. It requires investors, employees and value chain to have a deep understanding about the corporate's sustainability goals and to keep abreast of developments in the area.

From this perception, the real estate company has an educational approach that addresses the conditions for creating sustainable behaviour among their stakeholders. Responsible practices require important changes in the individual's culture, which are based on the ethical and moral examples of their power structure (e.g. $\mathrm{CEO}, \mathrm{CFO}$, board of directors). Therefore, the firm's value system, behaviour and performance criteria must be defined in line with ethics and morality, social equality and socioenvironmental justice (OECD, 2011; UNGC, 2014; GRI, 2018). Their objectives and actions, corporate strategy, as well as the way in which the organisation acts in the market, should focus on creating growth opportunities, competitive advantage and market position under the ESG principles such as profitability, social progress and environmental protection (Rapson et al., 2007; Reed \& Wilkinson, 2005).

The mutual dependence of society and business requires that corporate decisions and social policies incorporate good practices into their strategies to share values, that is, decisions must benefit both parties. If real estate businesses or society pursue policies that benefit only their own interests, the temporary benefit of one will weaken their long-term prosperity (Porter \& Kramer, 2006). Carrying it a bit further, the sustainable goals developed in the corporate strategic planning not only determine the bases of the tactical and operational process at the corporate administrative levels, but also the fundamentals of the portfolio management as well as the real estate business strategy. Since a strategy only makes sense when it is executed, the real estate development project is the vehicle to perform the social, economic and environmental strategies of the real estate company. Thus, a property development strategic planning should translate the sustainable goals into actions. The Figure 4 shows not only the key elements, which are design according to the sustainability aspects, but also the interrelation into these components to configure an information system across to the company's administrative levels. 


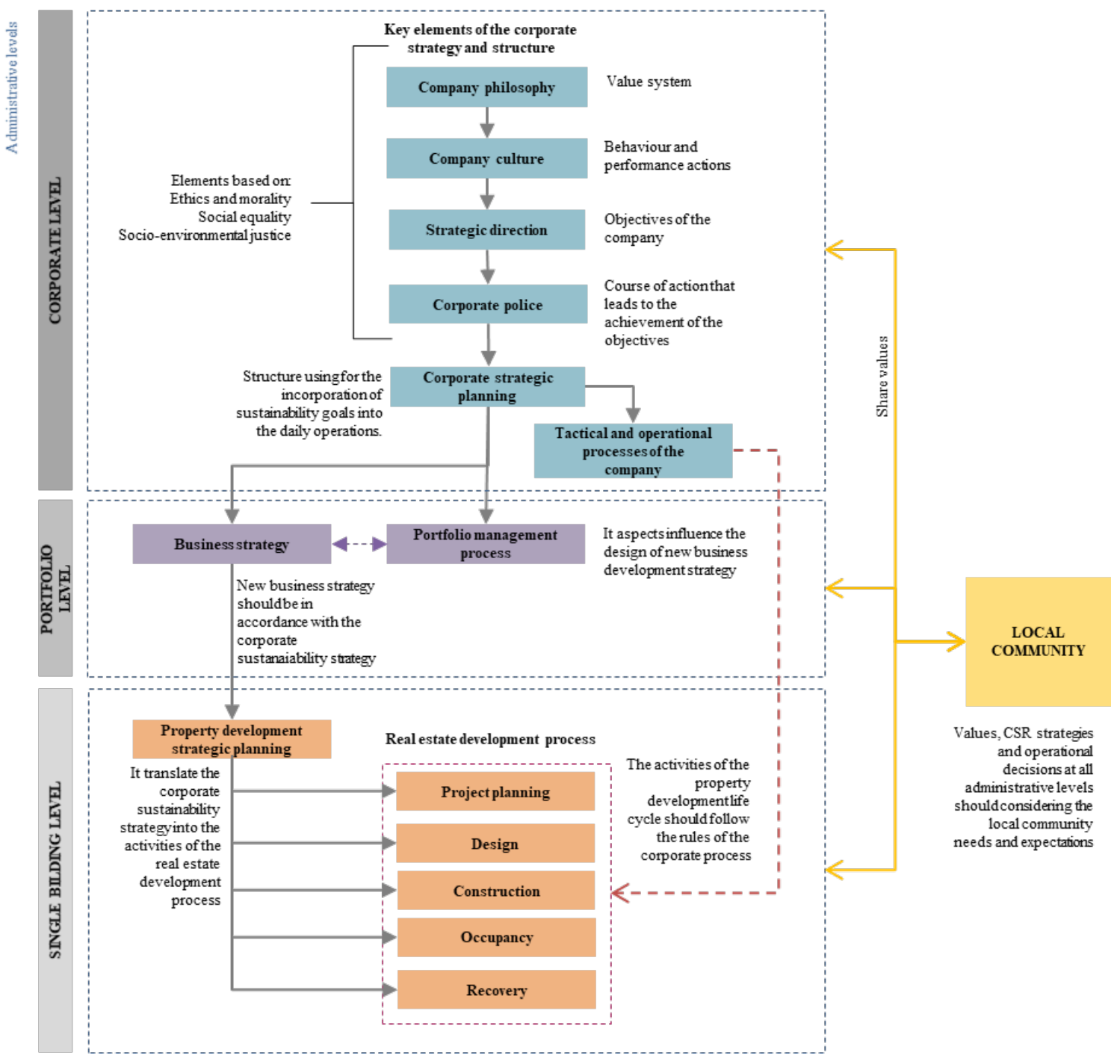

Figure 4 . The interrelation between the company's key elements for the creation of a sustainable information flow (source: elaborated by the authors)

This being considered, this section connects the core premises of sustainability with the main functions of business and building. From a practical perspective, this approach provides recommendations to help the commercial property professionals embed sustainable practices within their various activities.

\subsection{Recommendations for the incorporation of sustainable practices into the business strategy and management}

The CSR elements mentioned in the section 2.1 encompass core premises that could be considered are main drivers for the development of the sustainable strategy and actions of the company (Figure 4). These core premises can be divided into three main topics, which lead to good practices in corporate governance and should be interiorize by the stakeholders. However, it is important to consider that the core subject of each document is not exactly the same and, in most cases, similar issues are involved in different topics. Thus, it is important to highlight that the comparisons and equivalents are approximate depending on the authors' analysis and knowledge. The Figure 5 establishes a connexion between the main CSR topics, the CSR elements exposed in the section 2.1 and the core premises that define good practices at business level. Following the three main topics are:

- Business policies and management: The commercial property company should behave ethically. This topic covers transparency in company decisions and where activities impact local development and the community. It covers initiatives for compliance with laws and regulations, training and awareness raising for employees on the topics of eliminating bribery, anticorruption and extortion, promoting social responsibility in the value chain, consumer protection and fair business practices such as legal action for anti-competitive behaviour, anti-trust and monopoly practices (ISO, 2010; OECD, 2011; GRI, 2018). Their strategies should also respect and respond to the interests of its 
stakeholders. Moreover, their efforts for sustainability should be based on a due diligence process that verifies the extent to which such processes have been implemented to avoid incidents and violations.

- Environment protection and climate changes: The commercial property company should promote environmental responsibility in their employees and stakeholders. They should establish and maintain an environmental management system which includes strategies for monitoring and assessing the environ- mental and health and safety impacts of their activities. It should also involve contingency plans to prevent, mitigate and control severe damage to health and the environment, and report any incidents to the relevant authorities (ISO, 2010; OCDE, 2011; GRI, 2018).

- Employment and social development: According to the set of guidelines, the firm should respect internationally recognised human rights, the human rights obligations of the countries in which they operate and the relevant domestic laws and regulations. Corporate

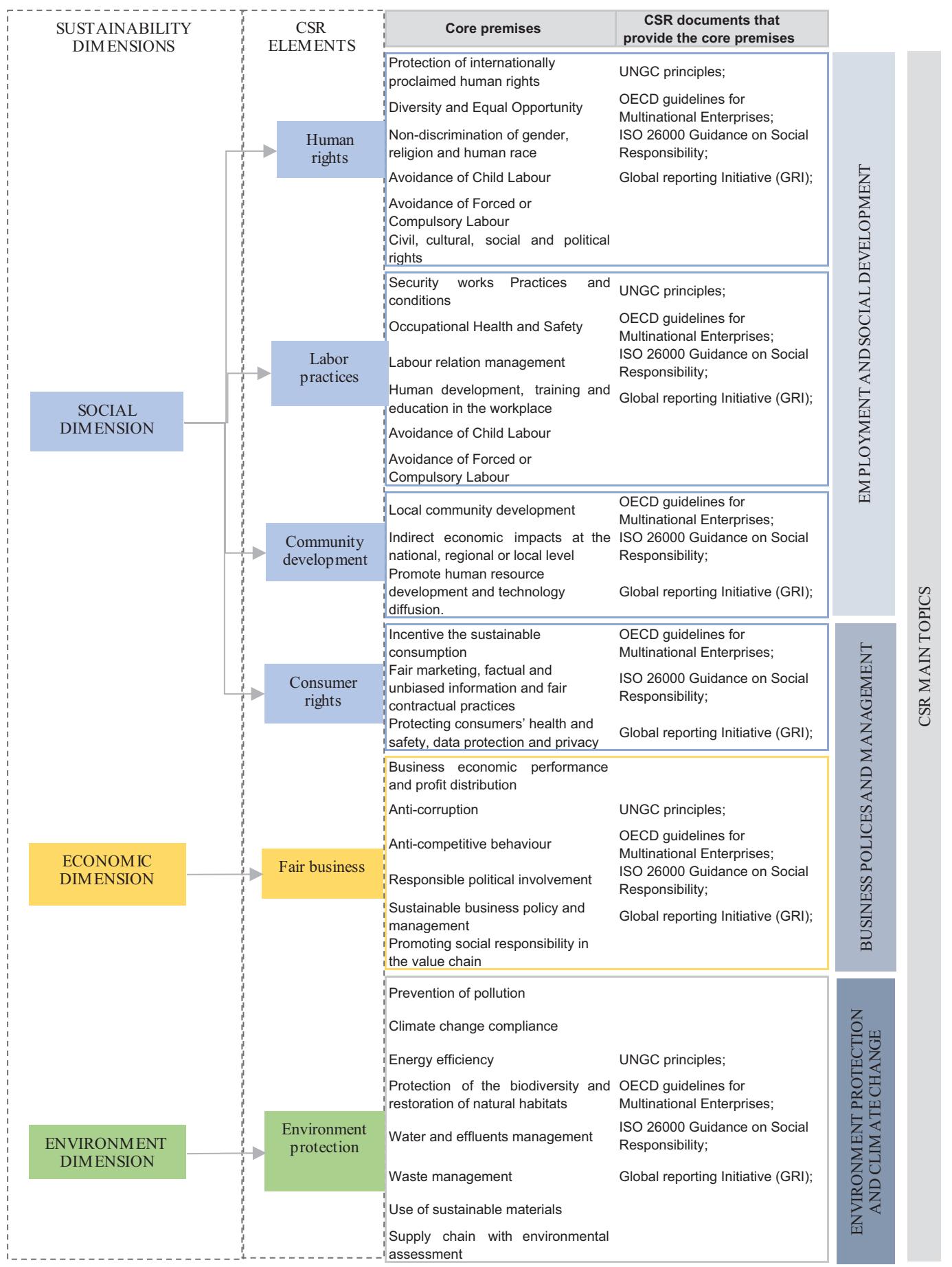

Figure 5. The CSR core premises used for commercial property corporate governance to create the company's values, actions and strategies (source: elaborated by the authors) 
governance must ensure that the human rights of their employees are respected across the organization, that members of their supply chain are also committed and the treatment of tenants and local communities does not violate any human rights (ISO, 2010; RICS, 2015; GRI, 2018). From this perspective, the commercial property organization should also establish management programmes which promote workers' health and wellbeing, gender equality, fair employment relationships that include the elimination of forced or compulsory labour, child labour and discrimination (ISO, 2010; GRI, 2018). This topic also addresses how businesses should demonstrate proactive commitment and involvement in the community to create employment, promote local social justice, science and technology, innovative capacity and community wealth. Furthermore, commercial property companies should work together with the local governments to develop safer and more inclusive cities.

Carrying these premises further, sustainable commercial property investment creates economic value by taking into account the ESG to avoid benefitting from social and environmental inequalities, such as poverty, pollution and improper competitive advantages. Therefore, looking into the portfolio management routines, professionals are required to have a deep understanding of the corporate sustainability strategies to be able to translate the sustainability targets into the organisational structures and create management tools for monitoring and reporting on sustainability performance. Thereby, in conjunction with the DCF methodologies, the decision-making process considers asset features that influence the balance of the profit distribution among stakeholders, local community development, as well as the business capability to create human, environmental and economic capital. According to UNEP FI (2014), sustainable portfolio management embraces analytical methods, which provide a profound analysis of the relationships between physical property features, corporate aims and economic success. Relevant recommendations are made on a minimum set of processes which an organisation can use to meet their sustainability goals while creating value for stakeholders, building occupants and local community (UNEP FI, 2014; RICS, 2015; GRESB, 2018).
- Design a reporting system to measure the sustainability performance of its whole portfolio and ensure that the measurement has a user-friendly data input interface for the organization's own staff and for the external service providers. The system should include social, economic and environmental KPIs that provide information in line with the core sustainability premises. Besides, it is important highlight that, this information system must be directly related to a CRS reporting guideline scheme (see Figure 1), which is more appropriate for detailing its performance to investors and society, e.g. managers of publicly traded companies can define KPIs that directly produce information in line with the GRI guideline issues. A dashboard management system interconnected with the reporting system decreases the probability of asymmetric information between internal and external stakeholders, contributes to a reduction in the dispersion of analysts' forecasts and thus an increase in information accuracy (Cuadrado-Ballesteros et al., 2017).

- Establish performance targets for a quality management approach, by which the property development and building operating process can be continuously improved.

- Certify that the input data and basic information on the property's physical, technical and management features is available for all assets within the portfolio.

Considering these administrative premises, the first stage of a sustainable project development is connected to the definition of the most appropriate business strategy according to the corporate objectives, investments success factors as well as the stakeholder's expectations (Morris \& Jamieson, 2004, 2005). Although the focus of a business strategy is strictly economic, CSR objectives need to drive it so that profit maximization does not override the company's social principles and values. Therefore, this approach expands the classic investment vision (i.e. security, liquidity and return) in order to balance the three aspects of sustainability at the strategic decision-making process (Figure 6). I.e. the company needs to balance its strategies of long-term value creation on three fundamental concepts of sustainability that interact and complement each other - [1] corporate social responsibility, [2] Responsible
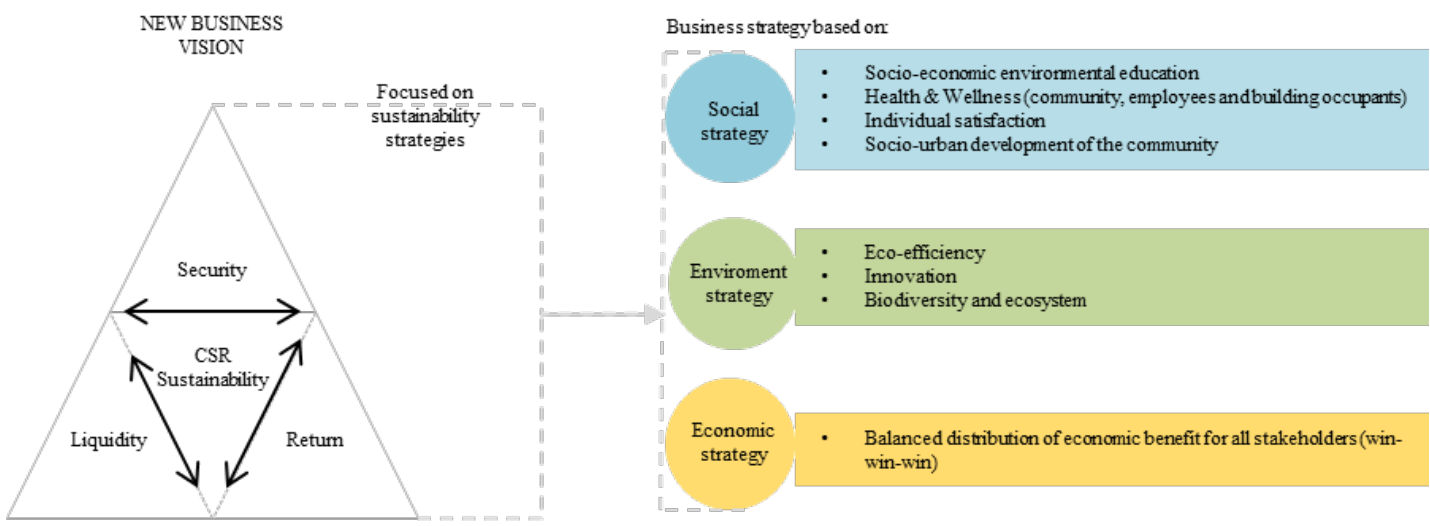

Figure 6. The new business investment vision and the main drivers of the sustainable business strategy (source: adapted from Lorenz, 2006; UNEP FI, 2014; Porter \& Kramer, 2006) 
real estate investment, and [3] sustainable buildings (UNEP FI, 2014). In this regard, business strategies give objective and tactical character to the company's sustainability policy.

\subsection{Recommendations for the sustainable building's development process}

The built environment reflects a corporation's sustainability strategies. Therefore, professionals should assess, monitor and report on sustainability performance over the building's whole life cycle i.e. planning, design, construction, occupancy and recovery. These activities must be in line with sustainable business policies such as transparency, good labour practices, human rights, CSR supply chain, as well as environmental protection. For this, the property development strategic planning is the instrument, which gives team members a sense of direction to achieve the sustainable objectives at the project level, i.e. it translates the dynamic of the corporate philosophy, culture and business strategies into the project management providing the drivers for the decision-making process at the various stages of the real estate development (Morris \& Jamieson, 2004). Besides, the strategic planning process permits managers to measure the project accomplishments against expectations (Hewlett, 1999).

Therefore, this approach establishes three strategic planning steps (Figure 7), which should be used to set up a document to communicate with the team the business goals and the actions to achieve these goals (Porter \& Kramer, 2006; Kerzner, 2001).

1. Formulation process - It understands the business strategy goals and defines the aspects to remain competitive within the business. It is performed by the top management values providing the decisive decision model for directing the course of business (Kerzner, 2001). There are three topics that should be formulate: - Analyze the external environment (e.g. market trends, political environment, competitor's behavior and risks) for changing conditions identifying sustainable opportunities or threats.

- Analyze the company's resource base and management capacity for asset strengths and weaknesses.
- Set project goals for pursuing the business strategy based on the sustainable values and sense of responsibility.

2. Implementation process - It stablishes rules and procedures in order to create a fit between the company's goals and its ongoing activities. According to Kerzner (2001) integration management is an important core competency of the project management.

3. The identification of the opportunity process - It establishes the logical decision-making process that could be part of the identification and selection of the new project. Checklists with the main sustainability goals can be created with the following topics to help directors and managers simplify the go-nogo process:

- The potential size of the market and market position.

- The expected competitive response.

- The acceptable potential risks for the business.

- The strategy for the land selection and acquisition to build the project.

- The capital requirements for the building development.

- The degree of social acceptance.

- Technical opportunities for the building construction.

- Supply chain management capabilities.

- Financial capabilities.

It should be noted that these criteria are one of the main bases for the identification and selection of business opportunities and the design of the real estate development. These strategic planning creates the standard methodology for the site selection process, negotiations and the project management (Hewlett, 1999). Therefore, comparing the issues in the set of the sustainable building schemes analysed, there are eight main topics which encompass core premises for the development of sustainable buildings:

1. Sustainable project management: professionals should integrate sustainability aspects into the main develop-

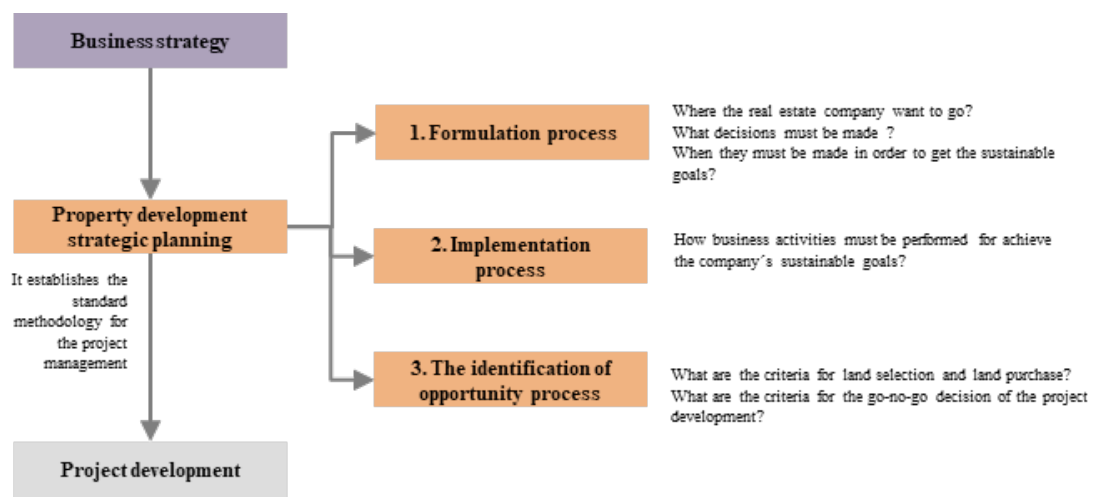

Figure 7. The new business investment vision and the main drivers of the sustainable business strategy (source: Kerzer, 2001; Porter \& Kramer, 2006) 
ment stages of the building i.e. commercial viability, project brief, design, construction, commissioning, occupancy and aftercare. This approach improves the building quality and ensures that economic, social and environment considerations form the backbone of strategic decisions which concern the quality of the asset. It also refers to the tenants' policies, which covers transparency and a responsible marketing, as well as the design of green leases and building user's manuals (BREEAM, 2018; DGNB, 2018).

2. Site selection and accessibility: This topic must to be taken to account at the commercial viability phase. It encourages developers and owners reuse brownfield terrain or those of low ecological value. The site selection must take to account sustainable premises for achieving a low soil-sealing factor, and a low environmental impact. Therefore, it encourages the recovery of degraded areas, habitat protection and creation of long-term biodiversity management. Site accessibility connects market analysis and transport communications which improve access to local amenities. Additionally, it takes into account sustainable, alternative transport solutions for building users, which supports the reduction of car use and, therefore, $\mathrm{CO}_{2}$ emissions over the building life cycle.

3. Community development: This topic addresses how businesses should demonstrate proactive commitment and involvement in the community to create employment, local social justice, science and technology, innovative capacity and community wealth. The commercial property organisation should work together with the local government to develop safer and more inclusive cities.

4. Functional and sustainable design: The building design should be accessible to everyone, without restrictions on its use. In addition, the project should optimise and facilitate the maintenance of building materials and systems. It is important that the project create quality indoor and outdoor spaces according to the occupiers' expectations, the marketing analysis and the weather conditions. Another important aspect is the inclusion of innovative measures to decrease the buildings impact and to increase economic performance and user comfort. The design must consider bioclimatic and low carbon strategies, which create sustainable building features such as building energy efficiency, daylight control and indoor air quality.

5. Materials and resources: Use of construction-efficient products that reduce the building's environmental and social impact. It is important to use the Building life cycle assessment (LCA) to evaluate the impact of products during manufacturing, design, procurement, installation, in-use and end-of-life. According to BREEAM (2018), this topic should focus on the efficiency of the construction product, its environmental impact, as well as responsible sourcing and product durability.
6. Sustainable worksite: The worksite team must monitor, evaluate and control the environmental impacts of construction such as: water, effluents and waste management, energy consumption and polluting emissions. In addition, social issues are extremely important such as workers health and safety, as well as the local community's wellbeing, limiting noise and visual pollution and optimising worksite cleanliness.

7. Environmental protection and climate change: In its building operating processes, the building management company should promote responsibility for the environment, its employees and its supply chain. According to the business objectives, the facility manager must institute and maintain an environmental management system that includes monitoring, evaluating and reporting on the environmental and health and safety impacts in the building's daily operations.

8. User comfort: This encourages the use of strategies that increase the health, wellbeing and safety of building occupants. This topic embraces issues which give incentives for building design specifications to create a comfortable internal and external environment.

These recommendations should be taken to account for the design of a KPI system for monitoring and reporting the sustainable performance of the building development process (i.e. planning, design, construction and occupancy). For this, managers should to build links between the company's management data platforms and the green labels (e.g. BREEAM, LEED), which are considered more asset-based reporting and certification methodology for the company's actuation market. The Figures $8 \mathrm{a}, 8 \mathrm{~b}$, $8 \mathrm{c}, 8 \mathrm{~d}, 8 \mathrm{e}$ relate the core premises to certifications criteria at each building development stages. However, it is important to note that some certification criteria vary across countries such as thermal comfort, regulations and policies. Therefore, managers must consider the local features where their buildings are located in order to create reliable indicators to measure and compare the performance of their portfolio.

As a final point, for a building to be considered sustainable it is important to understand the relationship between the dimensions of sustainability and the impact they have on the life cycle of the project. Therefore, an assessment system should focus on measuring the balance of the environmental, social and economic impacts at all stages of the building's development process. In order for this to happen, sustainable building schemes should incorporate into their assessment methods those issues which evaluate the direct impact that the building life cycle has on the development of the socio-economic community, on the wellbeing of the workers (from the construction to the operating stage), and how these aspects influence, and are connected to the local culture. 


\begin{tabular}{|c|c|c|c|c|c|c|c|}
\hline \multirow{14}{*}{ 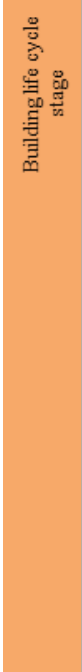 } & \multirow[t]{11}{*}{$\begin{array}{c}\text { Core protection } \\
\text { area }\end{array}$} & $\overline{1}$ & \multirow{6}{*}{$\begin{array}{l}\text { Core } \\
\text { protection } \\
\text { area }\end{array}$} & I & Core premise & $\begin{array}{l}\text { Documents that provide the } \\
\text { core premise }\end{array}$ & $\begin{array}{l}\text { Objectives involved in the documents that provide } \\
\text { the core premise }\end{array}$ \\
\hline & & i & & $\begin{array}{l}1 \\
1 \\
1\end{array}$ & Commercial viability & DGNB (ECO 2.2) & $\begin{array}{l}\text { Evaluate the property quality, site aspects and market } \\
\text { characteristics in order to increase its value, making it } \\
\text { substantially easier to position it on the market }\end{array}$ \\
\hline & & I & & । & \multirow{2}{*}{ Life cycle cost } & DGNB (ECO1.1) & \multirow{2}{*}{$\begin{array}{l}\text { It helps the team design visualise how the design } \\
\text { specifications can minimise the costs to the building } \\
\text { occupiers as well as maximise the value of the asset. }\end{array}$} \\
\hline & & 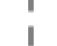 & & 1 & & BREEAM (Man02) & \\
\hline & & i & & I & \multirow{2}{*}{$\begin{array}{l}\text { Project brief and } \\
\text { stakeholder's } \\
\text { engagement }\end{array}$} & DGNB (PRO 1.1) & \multirow{2}{*}{$\begin{array}{l}\text { It ensure a transparent planning process to optimise } \\
\text { bvilding performance considering the stakeholders } \\
\text { necessities. }\end{array}$} \\
\hline & & I & & 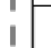 & & BREEAM (Man01) & \\
\hline & & 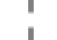 & Economic & 1 & \multirow{2}{*}{$\begin{array}{l}\text { FM compliant } \\
\text { planning }\end{array}$} & & \multirow{2}{*}{$\begin{array}{l}\text { It takes into account the requirements of FM for later } \\
\text { bvilding operation as aarly as in the planning phase. }\end{array}$} \\
\hline & & 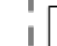 & capital & $\Gamma$ & & DGNB (PRO 2.5) & \\
\hline & & i & I & 1 & \multirow{2}{*}{$\begin{array}{l}\text { Commissioning and } \\
\text { handover }\end{array}$} & DGNB (PRO 2.3) & \multirow{2}{*}{$\begin{array}{l}\text { It aims a properly planned handover and commissioning } \\
\text { process, which ensure the building systematic operation } \\
\text { and reflect the needs of the building occupants. }\end{array}$} \\
\hline & & I & I & 1 & & BREEAM (Man04) & \\
\hline & & I & i & 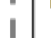 & & - & \\
\hline & $\begin{array}{l}\text { Sustainable } \\
\text { Project }\end{array}$ & ل & i & i & $\begin{array}{l}\text { User sustainability } \\
\text { guide }\end{array}$ & DGNB (PRO 2.4) & $\begin{array}{l}\text { rreating g guded to inform the users with regard to the } \\
\text { bvildings s sustainability and to incentive them to behave } \\
\text { in svch a way that the building is more sustainable. }\end{array}$ \\
\hline & management & I & & 1 & \multirow{3}{*}{$\begin{array}{l}\text { After care and } \\
\text { sustainable } \\
\text { management } \\
\text { guideline }\end{array}$} & & \multirow{3}{*}{$\begin{array}{l}\text { Providing aftercare support to the bvilding occupier and } \\
\text { information to the tenant and facility manager in a } \\
\text { clearly organized format in order to ensure the bvilding's } \\
\text { planned performance. }\end{array}$} \\
\hline & 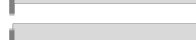 & I & I & I & & DGNB (PRO 1.5) & \\
\hline \multirow{29}{*}{ 哭 } & $\begin{array}{l}\text { Site selection and } \\
\text { accessibility }\end{array}$ & d & I & I & & BREEAM (Man05 & \\
\hline & I & 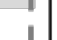 & $\mathbf{I}$ & I & \multirow{4}{*}{$\begin{array}{l}\text { Site selection and } \\
\text { ecosystem protection } \\
\text { (greenfield or } \\
\text { brownfield) }\end{array}$} & LEED (LT credit) & \multirow{4}{*}{$\begin{array}{l}\text { Use of previously occupied and or contaminated land } \\
\text { and avoid land which has not been previously disturbed. }\end{array}$} \\
\hline & I & 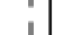 & I & I & & & \\
\hline & I & | & I & I & & BREEAM (LE01) & \\
\hline & I & i & I & I & & & \\
\hline & I & i & I & I & \multirow{4}{*}{$\begin{array}{l}\text { Study of the Land } \\
\text { Use and Ecology } \\
\text { risks management }\end{array}$} & LEED (LT credit) - & \multirow{4}{*}{$\begin{array}{l}\text { Identifying and understanding the risks and opportunities } \\
\text { for the site, managing the negatives impacts ecology. } \\
\text { Measuring the soil sealing factor and or compensatory } \\
\text { measures }\end{array}$} \\
\hline & I & i & I & I & & $\begin{array}{l}\text { BREEAM (from LE02 to } \\
\text { LE05) }\end{array}$ & \\
\hline & I & i & Ecosystem & H & & DGNB (ENV2.3) - & \\
\hline & I & $\mathbf{I}$ & 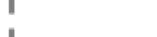 & 1 & & & \\
\hline & I & $\mathbf{I}$ & 1 & 1 & \multirow{2}{*}{$\begin{array}{l}\text { Protect or restore the } \\
\text { natural habitat and } \\
\text { the Biodiversity }\end{array}$} & LEED (LT credit) & Creating, maintaining and increasing biodiversity both \\
\hline & I & 1 & 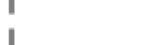 & 1 & & DGNB (ENV2.4) - & \\
\hline & 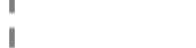 & I & i & 更 & & DGNB (SITE1.1) - & Protecting the building and its wers from the impact of \\
\hline & i & I & i & i & environment & CASBEE (LR3. 2 and 3 ) & negative environmental influences and extreme events. \\
\hline & I & 1 & I & I & & & \\
\hline & I & 1 & I & I & Incentive of green & LEED (LT credit) - & Reducing traffic-related emissions into the air, water \\
\hline & I & 1 & I & i & vehicles and the & BREEAM (Tra02) & $\begin{array}{l}\text { and soll via sustantanale moblitty ynfrastructure. } \\
\text { Encouraging and reward a building that is located in }\end{array}$ \\
\hline & I & 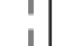 & $\mathbf{I}$ & $\mathbf{I}$ & & DGNB (TEC3.1); & $\begin{array}{l}\text { close proximity to local amenities, thereby reducing the } \\
\text { need for extended travel or multiple trips }\end{array}$ \\
\hline & I & 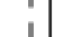 & I & I & & & \\
\hline & I & t & $\mathbf{I}$ & I & $\begin{array}{l}\text { Accessbility of the } \\
\text { building site and }\end{array}$ & DGNB (SITE1.3) - & $\begin{array}{l}\text { Promote sustainable mobility in various forms for the } \\
\text { bvilding's vers and attending their day-to-day needs }\end{array}$ \\
\hline & I & 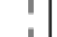 & I & I & Social infrastructure & $(1-4)$ & through the provision of nearby, accessible social and \\
\hline & $\mathbf{I}$ & T & 1 & I & proximity & & \\
\hline & $\mathbf{I}$ & t & 7 Social equity & $\Pi$ & & LEED (L T credits) & Creating an intelligent traffic infrastructure to allow \\
\hline & I & i. & I & I & Transport access and & & wers to choose the most appropriate means of transport \\
\hline & I & i. & I & I & $\begin{array}{l}\text { mobility } \\
\text { infrastucucture }\end{array}$ & BREEAM (Tran01, 02); & The calculation of the public transport \\
\hline & I & 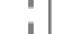 & I & I & & DCIR (CITE1 3) (TFC3 1) & accessibility index. \\
\hline & I & 1 & I & I & & DGNB (SITE1.3) (TEC3.1); & Travel plan measures \\
\hline & I & 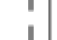 & I & I & & LEED (LT credits) & Planning a site location and bvilding design, which \\
\hline & I & 1 & Health and & ᄂ & Bicycle facilities & BREEAM (Tra02) & $\begin{array}{l}\text { encourage healthy bicycle and foot traffic in order to } \\
\text { improve the vser life's quality and decrease the }\end{array}$ \\
\hline & I & i & & I & & DGNB (TEC3.1) & pollution. \\
\hline
\end{tabular}




\begin{tabular}{|c|c|c|c|c|c|c|c|c|}
\hline \multirow{4}{*}{ 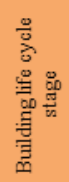 } & i & \multirow[t]{9}{*}{$\begin{array}{l}\text { Core protection } \\
\text { area }\end{array}$} & 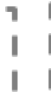 & \multirow[t]{7}{*}{$\begin{array}{l}\text { Core } \\
\text { protection } \\
\text { area }\end{array}$} & i & Core premise & $\begin{array}{l}\text { Documents that provide the } \\
\text { core premise }\end{array}$ & $\begin{array}{l}\text { Objectives involved in the documents that provide } \\
\text { the core premise }\end{array}$ \\
\hline & i & & 1 & & 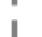 & \multirow{5}{*}{$\begin{array}{l}\text { Neighborhood } \\
\text { Development to } \\
\text { enhance livability } \\
\text { and improve human } \\
\text { health }\end{array}$} & \multirow{5}{*}{$\begin{array}{l}\text { LT Credit: LEED for } \\
\text { Neighborhood Development } \\
\text { Location }\end{array}$} & \multirow{5}{*}{$\begin{array}{l}\text { Site planning and bvilding design to enhance livability } \\
\text { and improve human health by encouraging daily physical } \\
\text { activity. }\end{array}$} \\
\hline & & & & & & & & \\
\hline & T & & I & & T & & & \\
\hline & I & & I & & I & & & \\
\hline & $\mathbf{I}$ & & 11 & & I & & & \\
\hline & I & & $\mathbf{I}$ & & $\mathbf{I}$ & \multirow{2}{*}{$\begin{array}{l}\text { Healthy building } \\
\text { surrounding }\end{array}$} & \multirow{7}{*}{$\begin{array}{l}\text { BREEAM (Po1 04) } \\
\text { BREEAM (Po1 05) } \\
\text { HQE (Target 1) } \\
\text { HQE (Sitel.3) } \\
\text { CASBEE (LR3.3) }\end{array}$} & \multirow{7}{*}{$\begin{array}{l}\text { The design of the bvilding should consider its impacts on } \\
\text { the well being of the local residents, avoiding materials } \\
\text { and equipment that generate pollution. }\end{array}$} \\
\hline & I & & $\mathbf{I}$ & Health and & 1 & & & \\
\hline & I & & 1 & well-being & r & & & \\
\hline & I & Community & $1]$ & 1 & 1 & time light pollution & & \\
\hline & I & development & I & I & $\mathbf{I}$ & \multirow{3}{*}{$\begin{array}{l}\text { Reduction of noise } \\
\text { pollution }\end{array}$} & & \\
\hline & I & & I & I & $\mathbf{I}$ & & & \\
\hline & I & & $\mathbf{I}$ & I & I & & & \\
\hline & $\mathbf{I}$ & & $\mathbf{I}$ & Segielervitzo & 1 & Design for all - & & \\
\hline & I & & I & Socral equity & $\Gamma$ & Building accessible & & To design the entire brilt environment accessible to \\
\hline & I & & $\mathbf{I}$ & I & I & $\begin{array}{l}\text { to everyone and } \\
\text { without restrictions }\end{array}$ & DGNB (SOC2.1) & $\begin{array}{l}\text { everyone and wthout restrictions on tts use, whatever } \\
\text { their personal situation. }\end{array}$ \\
\hline & I & & $\mathbf{I}$ & | & I & onits use & & \\
\hline & I & & I & I & I & & DGNB (SOC1.6); & Designing high-quality indoor and outdoor spaces that \\
\hline & I & & I & Health and & 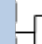 & $\begin{array}{l}\text { Quality of indoor and } \\
\text { outdoor spaces }\end{array}$ & $\begin{array}{l}\text { LEED (SS credit); } \\
\text { HOE (Target } 1: 1.2)\end{array}$ & $\begin{array}{l}\text { accommodate as wide a variety of recreational and } \\
\text { functional uses as possible and increase the comfort. }\end{array}$ \\
\hline & I & & I & well-being & & & HQE (1 arget 1:1.2) & functional uses as possible and increase the comfort. \\
\hline & I & & I & $\mathbf{I}$ & I & $\begin{array}{l}\text { Limiting } \\
\text { electromagnetic }\end{array}$ & $\mathrm{HQE}$ (target: 12.1.) & Creating special health conditions for limit the impact of \\
\hline & I & & I & I & I & exposure & & sources of electromagnetic emissions \\
\hline & I & & I & | & I & & BREEAM (Mat 05); & Flexible design minimising the frequency of replacement \\
\hline & ! & & I & | & I & durability and & $\begin{array}{l}\text { DGNB (ECO2.1); } \\
\text { LEED MR CREDIT. }\end{array}$ & and maximising materials optimisation contributing to \\
\hline & 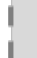 & $\begin{array}{l}\text { Functional and } \\
\text { sustainable }\end{array}$ & If & | & $\mathbf{I}$ & resilience & $\begin{array}{l}\text { HQE (Target } 2: 2.1 .) \\
\text { CASBEE Q2.3 }\end{array}$ & $\begin{array}{c}\text { bvilding's service life and lower costs incurred } \\
\text { throughout its life cycle. }\end{array}$ \\
\hline & 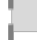 & design & 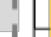 & Economic & & & BRFFAM ( & To support innovation with new technology or \\
\hline & 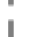 & & 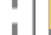 & & t & Innovative design & LEED IN credit & construction method, improving the sustainability \\
\hline & | & & i & | & I & & & operation, maintenance or demolition \\
\hline & | & & $\mathbf{I}$ & $\mathbf{I}$ & $\mathbf{I}$ & Optimising the for & $\mathrm{HQE}$ (Target $7: 7.1)$ & 1 and technical measures to reduce \\
\hline & $\mathbf{I}$ & & $\mathbf{I}$ & $\mathbf{I}$ & $\mathbf{I}$ & $\begin{array}{l}\text { simplified } \\
\text { maintenance }\end{array}$ & $\begin{array}{l}\text { HQE (Target 2:2.2.) } \\
\text { DGNB (TEC1.5) }\end{array}$ & the cost and effort required for cleaning \\
\hline & I & & $\mathbf{I}$ & I & I & Quality of the & DGNB (TEC1.3); & A well-planned bvilding envelope is a requirement for \\
\hline & I & & I & I & I & building envelope & CASBEE Q3.1 & achieving high user comfort and low energy costs \\
\hline $\bar{n}$ & I & & I & I & $\mathbf{T}$ & & BREEAM (Ene 04) & To use passive energy design which reduce bvilding \\
\hline Q̆ & I & & I & Natural & 1 & Low carbon design & $\mathrm{HQE}$ (Target $4: 4.1$.) & energy consumption. \\
\hline & I & & I & resources & & Building technology & BREEAM (Ene 02, 05,06,07); & \\
\hline & I & & I & I & 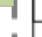 & for the energy & DGNB(TEC1.4); & equipment that support the sustainable use of energy in \\
\hline & I & & I & I & I & efficiency & $\begin{array}{l}\text { LEED EA CREDIT; } \\
\text { CASBEE LR1.3 }\end{array}$ & the bvilding \\
\hline & I & & I & I & I & Adaptation to climate & BREEAM (Wst 05) & Bvilding's solutions to mitigate the impact of extreme \\
\hline & I & & $\mathbf{I}$ & I & $\mathbf{I}$ & change & DREEAM (WSt US) & weather conditions \\
\hline & | & & $\mathbf{I}$ & I & $\mathbf{I}$ & Air quality (Air & BREEAM Hea 02; & \\
\hline & $\mathbf{I}$ & & 1 & I & I & emissions control, & $\begin{array}{l}\text { DGNB (SOC1.2); } \\
\text { LEED EO CREDIT; }\end{array}$ & $\begin{array}{l}\text { Healthy internal environment through the specification } \\
\text { and installation of appropriate ventilation, equipment and }\end{array}$ \\
\hline & $\mathbf{I}$ & User's comfort & 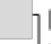 & $\mathbf{I}$ & I & $\begin{array}{l}\text { Reduction or } \\
\text { pollution) }\end{array}$ & HQE Target 13; CASBEE Q1.4 & finishes \\
\hline & I & & $\mathbf{I}$ & | & | & & & \\
\hline & I & & $\mathbf{I}$ & $\mathbf{I}$ & I & Visual comfort & $\begin{array}{l}\text { BREEAM Hea 01, DGNB } \\
\text { (SOC1.4); LEED EQ CREDIT; }\end{array}$ & $\begin{array}{l}\text { To ensure best practice in visual performance and } \\
\text { comfort for bvilding occupants, considering daylight and }\end{array}$ \\
\hline & I & & $\mathbf{I}$ & $\mathbf{I}$ & I & & HQE Target 1; CASBEE Q1.3 & artificial lighting control. \\
\hline & I & & I & Wh th & 1 & & BREEAM Hea 04; DGNB & To ensure that appropriate thermal comfort levels are \\
\hline & I & & $\mathbf{I}$ & Health and & ـ & Thermal comfort & (SOC 1.1); LEED EQ & achieved through design, and controls are selected to \\
\hline & I & & $\mathbf{I}$ & & I & & CASBEE Q1.2 & $\begin{array}{l}\text { occupants within the building. } \\
\text { ofint }\end{array}$ \\
\hline & I & & $\mathbf{I}$ & I & I & Olfactory comfort & HQE Target 11:11.1 & Controlling the sources of unpleasant odors \\
\hline & I & & $\mathbf{I}$ & I & I & & & \\
\hline & I & & $\mathbf{I}$ & I & I & Acoustic comfort & $\begin{array}{l}\text { BREEAM Hea 05; DGNB } \\
\text { SOC1.3; LEED EQ CREDIT; }\end{array}$ & $\begin{array}{l}\text { To ensure the building's acoustic performance including } \\
\text { sound insvlation meet the appropriate standards for its }\end{array}$ \\
\hline & $\mathbf{I}$ & & $\mathbf{I}$ & I & | & & HQE Target 9; CASBEE Q1.1 & purpose \\
\hline & | & & $\mathbf{I}$ & I & I & Safety and security & & \\
\hline & I & & $\mathbf{I}$ & I & I & of the building and & $\begin{array}{l}\text { BREEAM Hea06, HeaO/; } \\
\text { DGNB (SOC1.7) }\end{array}$ & $\begin{array}{l}10 \text { encourage ettective measures that promote sate and } \\
\text { secure use and access to and from the bvilding }\end{array}$ \\
\hline & $\mathbf{I}$ & & $\mathbf{I}$ & I & $\mathbf{I}$ & & & \\
\hline & $\mathbf{I}$ & & & $\mathbf{I}$ & I & Building life cycle & BREEAM (Mat 01); & To measure the environmental impact of the material \\
\hline & I & resources & & $\mathbf{I}$ & $\mathbf{I}$ & assessment (LCA) & DGNB (ENV1.1) & over the full life cycle of the bvilding \\
\hline & $\mathbf{I}$ & & $\mathbf{T}$ & | & $\mathbf{I}$ & Responsible sourcing & BREEAM (Mat 03); DGNB & \\
\hline & I & & $\mathbf{I}$ & Natural & 1 & of construction & $\begin{array}{l}\text { (ENV1.2); LEED MR } \\
\text { CREDIT;; HQE (Target 2: } 2.3 \text {, }\end{array}$ & $\begin{array}{l}\text { To recognise and encourage the specification of } \\
\text { responsibly sourced materials for key bvilding elements }\end{array}$ \\
\hline & I & & $\mathbf{I}$ & resources & $\Gamma$ & & 2.4); CASBEE (LR2.2) & \\
\hline & I & & $\mathbf{I}$ & I & I & Material efficiency & BREEAM (Mat 06) & To measure the environmental impact of material use and \\
\hline & I & & I & I & I & & & Thaste. \\
\hline & I & & $\mathbf{I}$ & I & $\mathbf{I}$ & $\begin{array}{l}\text { Use of recycled and } \\
\text { sustainably sourced }\end{array}$ & BREEAM (Wst 02) & $\begin{array}{l}\text { To use of recycled and secondary aggregates, optimising } \\
\text { material efficiency in construction. }\end{array}$ \\
\hline & L & ---- & & $\mathbf{L}---$ & & aggregates & & \\
\hline
\end{tabular}




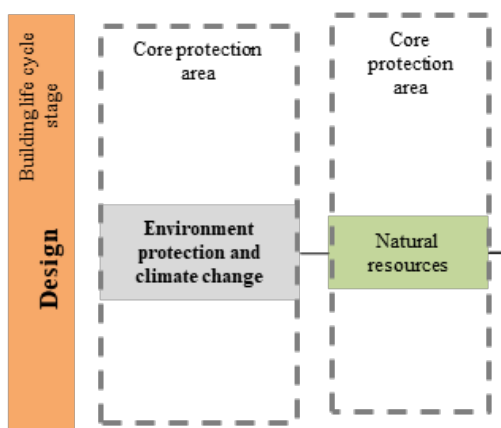

\begin{tabular}{|c|c|}
\hline Core premise & $\begin{array}{l}\text { Documents that provide the } \\
\text { core premise }\end{array}$ \\
\hline $\begin{array}{l}\text { Reduction of energy } \\
\text { use and carbon } \\
\text { emissions }\end{array}$ & \multirow{2}{*}{$\begin{array}{l}\text { BREEAM (Ene } 01 \text { to Ene08); } \\
\text { DGNB (TEC1.4); LEEED E. } \\
\text { credit; HQE target 7.1, target 4; } \\
\text { CASBEE }\end{array}$} \\
\hline $\begin{array}{l}\text { Energy efficient cold } \\
\text { storage }\end{array}$ & \\
\hline $\begin{array}{c}\text { Water leak detection } \\
\text { system }\end{array}$ & \multirow{2}{*}{$\begin{array}{l}\text { BREEAM (Wat } 01 \text { to Wat 04); } \\
\text { DGNB (ENV2.2); LEED WE } \\
\text { CREDIT; HQE target 5, Target } \\
\text { 14; CASBEE LR2. } 1\end{array}$} \\
\hline $\begin{array}{c}\text { Water efficient } \\
\text { equipment }\end{array}$ & \\
\hline
\end{tabular}

c)

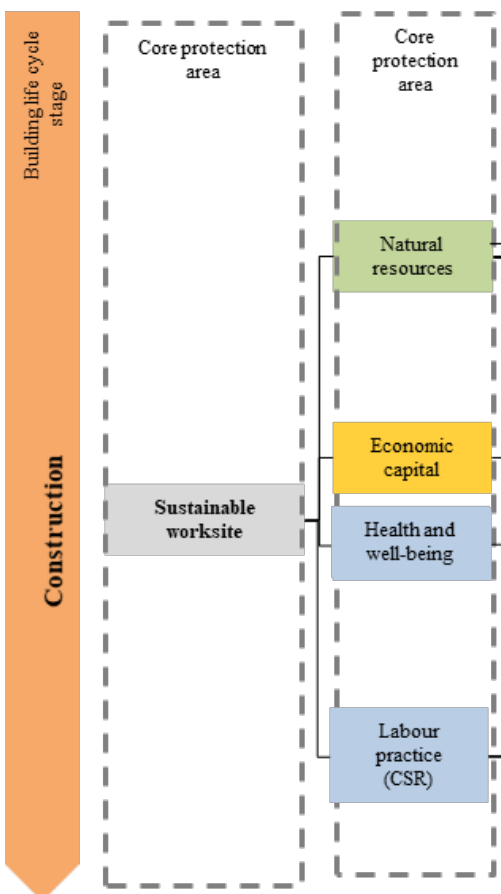

\begin{tabular}{|c|c|c|}
\hline Core premise & $\begin{array}{l}\text { Documents that provide the } \\
\text { core premise }\end{array}$ & $\begin{array}{l}\text { Objectives involved in the documents that provide } \\
\text { the core premise }\end{array}$ \\
\hline $\begin{array}{l}\text { Soil and groundwater } \\
\text { protection on the } \\
\text { construction site }\end{array}$ & DGNB (PRO2.1); & $\begin{array}{l}\text { Stablishing measures to minimise the negative impact on } \\
\text { the local environment during the construction phase. }\end{array}$ \\
\hline $\begin{array}{c}\text { Environmental } \\
\text { management }\end{array}$ & BREEAM (Man 03) & $\begin{array}{l}\text { To encourage construction sites which are managed in an } \\
\text { environmentally and socially and manner. }\end{array}$ \\
\hline $\begin{array}{l}\text { Low-waste } \\
\text { construction site }\end{array}$ & $\begin{array}{l}\text { DGNB (PRO2.1) } \\
\text { HQE (target } 3: 3.3,3.1) \\
\text { LEED MR CREDIT }\end{array}$ & Measures to decrease the waste in the construction site \\
\hline Wastemanagement & $\begin{array}{l}\text { BREEAM Wst 01; DGNB } \\
\text { (PRO2.1); LEED MR } \\
\text { CREDIT: }\end{array}$ & $\begin{array}{l}\text { To promote resource efficiency via the effective } \\
\text { management and reduction of construction waste. }\end{array}$ \\
\hline $\begin{array}{l}\text { Quality as surance of } \\
\text { the construction }\end{array}$ & DGNB (PRO2.2) & $\begin{array}{l}\text { to ensure that the requirements from the planning stage } \\
\text { are appropriately implemented by conducting } \\
\text { informative quality assurance processes during the } \\
\text { construction phase. }\end{array}$ \\
\hline $\begin{array}{l}\text { Low-noise and Low- } \\
\text { dust construction site }\end{array}$ & $\begin{array}{l}\text { DGNB (PRO2.1); } \\
\text { HQE (target } 3: 3.2)\end{array}$ & $\begin{array}{c}\text { Measures to guarantee the ow-noise construction site and } \\
\text { low-dust construction site }\end{array}$ \\
\hline $\begin{array}{l}\text { Security works } \\
\text { Practices and } \\
\text { conditions }\end{array}$ & CRESS GRI - CRE06 & $\begin{array}{l}\text { The company should specify how occupational health } \\
\text { and safety risks are identified and managed to prevent } \\
\text { incidents, injuries or deaths in the workplace. }\end{array}$ \\
\hline $\begin{array}{l}\text { Avoidance of Forced } \\
\text { or Compulsory } \\
\text { Labour }\end{array}$ & CRESS GRI - G4-DMA & $\begin{array}{l}\text { The company must ensure good work practices with } \\
\text { adequate remuneration. }\end{array}$ \\
\hline $\begin{array}{l}\text { Human development, } \\
\text { training and } \\
\text { educationin the } \\
\text { workplace }\end{array}$ & CRESS GRI - G4-LA9 & $\begin{array}{l}\text { The company should focus on categories of training svch } \\
\text { as vocational training, apprenticeships and occupational } \\
\text { health and safety training provided to workers (especially } \\
\text { site management) }\end{array}$ \\
\hline
\end{tabular}

d) the core premise

Measures to encourage bvildings designed to minimise operational energy demand, consumption and $\mathrm{CO}_{2}$ emissions. water efficient components and water recycling systems.
Objectives involved in the documents that provide

To reduce the consumption of potable water for sanitary use in new brildings from all sources through the use of 


\section{Discussions}

The core premises identified in the above sections show that the employment of practical sustainability in the commercial property business goes significantly beyond the issues of the built environment. There is a variety of social and economic aspects associated with business management which not only influence a commercial property firm's strategic planning, but also affects the decisionmaking process for building development and asset management. It is also important to highlight that commercial properties are a complex business, in which different company areas (corporate, asset and building management) create a complex web of interconnected information flows and requirements (UNEP FI, 2014). Therefore, thinking in a sustainable way encompasses a wide range of physical, social, environmental and economic factors that directly influence company strategies and the asset value.

Carrying this issue further, the current concept of sustainability used in the market is insufficient since it focuses mainly on the environmental building impact. Socio-economic aspects are seen as corporate initiatives and usually do not interrelate with the complete building life cycle. If just the green building certification is used to assess the property's sustainability performance, the property's impact will be only partially measured, as these certificates focus on a small section of the sustainability characteristics that should be used by commercial property businesses. Therefore, not only the performance of the building components and equipment must be assessed, but also all socioeconomic actions in its value chain such as business transparency, good practices in the land selection and acquisition, labour relationship and the construction practices.

For that, a holistic approach helps commercial property's professionals visualise all elements and objectives of the process and their interrelationship with the social, environmental and economic strategy of the company. This interrelationship set out in the approach facilitates the promoter to explain what are the necessary changes in the modus operandis of the professionals covered in the process, so that such information could be consistent and assertive.

\section{Conclusions}

Incorporating sustainability into the commercial property market is still somewhat confused and subjective. Therefore, this paper intends to link sustainability, real estate environmental, social, and governance (ESG) and sustainable building in order to help companies internalise this concept in all areas of their operations aligning it with their strategic planning. Sustainability must be comprehensively understood as part of a single system in which different disciplines are interrelated. Thus, the decisions made at each business level directly influence the results of the other activities, and consequently the final impact of the process. However, this attitude demands a cultural change and advances in the way that business is planned. This would also imply significant changes in the business model still used by corporations in the sector.

In accordance with this, the holistic approach proposed provides organisations with two key drivers to shift its modus operandi towards sustainability:

- Core premises that help professionals to organize the collection, monitoring and controlling of sustainability goals at corporate, portfolio and single building levels. It facilitates the evaluation and implementation of sustainable strategies across all business process activities.

- Information for correct data collection, input and reading on the sustainability issues in order to create the necessary materials for professionals to analyse the business risks and opportunities, as well as correctly design the management process and impact mitigation.

To conclude, this research provides some recommendations that can stimulate further studies to provide broader and deeper information to create solid, sustainable assessment tools and to develop metrics capable of completely incorporating the dimension of sustainability into the valuation of the commercial property business.

\section{References}

Atanda, J. O. (2019). Developing a social sustainability assessment framework. Sustainable Cities and Society, 44, 237-252. https://doi.org/10.1016/j.scs.2018.09.023

Benani, R., Vahdati, M., \& Elmualim, A. (2013). Demonstrating the importance of criteria and sub-criteria in building assessment methods. WIT Transactions on Ecology and the Environment, 173, 443-454. https://doi.org/10.2495/SDP130371

Berardi, U. (2012). Sustainability assessment in the construction sector: rating systems and rated buildings. Sustainable Development, 20, 411-424. https://doi.org/10.1002/sd.532

Bernet, J. R., Sayce, S., Vermeulen, M., \& Ledl, C. (2010). Winning in the long run? A quantified approach to the drivers of sustainable financial value on real estate (Working paper 2, 25-07-2010, V5). https://eprints.kingston.ac.uk/18125/1/ Sayce-S-18125.pdf

BREEAM. (2018). BREEAM new constructions 2018 - technical manual. BRE Global Ltd. https://www.breeam.com/NC2018/

CASBEE. (2011). CASBEE for new construction. Comprehensive assessment system for built environment efficiency. http://www.ibec.or.jp/CASBEE/english/overviewE.htm

Cox, M., Brown, M. A., \& Sun, X. (2013). Energy benchmarking of commercial buildings: a low-cost pathway toward urban sustainability. Environmental Research Letters, 8(3), 1-12. https://doi.org/10.1088/1748-9326/8/3/035018

Cuadrado-Ballesteros, B., Martínez-Ferrero, J., \& GarcíaSánchez, I. M. (2017). Mitigating information asymmetry through sustainability assurance: the role of accountants and levels of assurance. International Business Review, 26(6), 1141-1156. https://doi.org/10.1016/j.ibusrev.2017.04.009

Deloitte. (2014). Breakthrough for sustainability in commercial real estate. Delloite development Center LCC. https://deloitte. wsj.com/cfo/files/2014/11/sustainable_real_estate.pdf

DGNB. (2018). The DNGB system: global benchmark for sustainability. https://www.dgnb-system.de/en/index.php 
Díaz-Lopez, C., Carpio, M., Martín-Moralez, M., \& Zamorano, M. (2019). Analysis of the scientific evolution of sustainable building assessment methods. Sustainable Cities and Society, 49, 101610. https://doi.org/10.1016/j.scs.2019.101610

Dixon, T., Colantonio, A., Shiers, D., Reed, R., Wilkinson, S., \& Gallimore, P. (2008). A green profession? A global survey of RICS members and their engagement with the sustainability agenda. Journal of Property Investment and Finance, 26(6), 460-481. https://doi.org/10.1108/14635780810908352

Doan, D. T., Ghaffarianhoseini, A., Naismith, N., Zhang, T., Ghaffarianhoseini, A., \& Tookey, J. (2017). A critical comparison of green building rating systems. Building and Environment, 123, 243-260. https://doi.org/10.1016/j.buildenv.2017.07.007

Eichholtz, P., Kok, N., \& Quigley, J. M. (2010). Doing well by doing good? Green office buildings. The American Economic Review, 100(5), 2492-2509.

https://doi.org/10.1257/aer.100.5.2492

Fuerst, F., Rottke, N., Zietz, J., \& Reichardt, A. (2012). Sustainable building certification and the rent premium: a panel data approach. Journal of Real Estate Research, 34(1), 99-126.

GRESB. (2018). Global Real Estate Sustainability Benchmark (GRESB), Developer reference guide 2018.

https://gresb.com/gresb-developer-assessment/

GRI. (2018). GRI Standards. Amsterdam, The Netherlands. https://www.globalreporting.org/standards/gri-standardsdownload-center/

Hemphill, T. (2013). The ISO 26000 guidance on social responsibility international standard: what are the business governance implications? Corporate Governance, 13(3), 305-317. https://doi.org/10.1108/CG-08-2011-0062

Hewlett, C. A. (1999). Strategic planning for real estate companies. Journal of Property Management, 64(1), 26-29.

Ho, D., Chau, K., Leung, H., Wong, S., Cheung, A., Yau, Y., Lau, S., \& Wong, W. (2005, September 27-29). A sustainable framework of building quality assessment for achieving a sustainable urban environment. Paper presented at the 2005 World Sustainable Building Conference, Tokyo (SB05Tokyo).

HQE. (2018). HQE Cerway brochure. Haute Qualité Environmentale. https://www.behqe.com/schemes-and-documents

ISO. (2008). Sustainability in building construction - General principles (ISO 15392:2008). https://www.iso.org/standard/40432.html

ISO. (2010). Guidance on social responsibility (ISO 26000:2010). https://www.iso.org/standard/42546.html

ISO. (2011). Sustainability in building construction - Sustainability indicators - Part 1: Framework for the development of indicators for buildings (ISO TS 21929-1:2011).

https://www.iso.org/standard/46599.html

ISO. (2017). ISO 26000 and OECD guidelines - Practical overview of the linkages. Vernier, Geneva, Switzerland. https://www.iso. org/files/live/sites/isoorg/files/store/en/PUB100418.pdf

Kerzner, H. (2001). Strategic planning for project management using a project management maturity model. Wiley.

LEED. (2018). LEED v4 BD+C rating system. https://www.usgbc. org/resources/leed-v4-building-design-and-constructioncurrent-version

Lorenz, D. (2006). The application of the sustainable development principles to the theory and practice of property valuation (Vol. 1 of Karlsruher Schriften zur Bau-, Wohnungs- und Immobilienwirtschaft). Universitat Verlag Karlsruhe.

Mahmoud, S., Zayedb, T., \& Fahmyc, M. (2019). Development of sustainability assessment tool for existing buildings. Sustainable Cities and Society, 44, 99-119.

https://doi.org/10.1016/j.scs.2018.09.024
Morris, P., \& Jamieson, A. (2004). Translating corporate strategy into project strategy. Project Management Institute.

Morris, P., \& Jamieson, A. (2005). Moving from corporate strategy to project strategy. Project Management Journal, 36(4), 5-18. https://doi.org/10.1177/875697280503600402

OECD. (2011). OECD guidelines for multinational enterprises. OECD Publishing. https://doi.org/10.1787/9789264115415-en

Porter, M. E., \& Kramer, M. R. (2006). Strategy \& society: the link between competitive advantage and corporate social responsibility. Harvard Business Review, 84, 78-85.

Rapson, D., Shiers, D., Roberts, R., \& Keeping, M. (2007). Socially responsible property investment (SRPI) an analysis of the relationship between SRI and UK property investment activities. Journal of Property Investment \& Finance, 25(4), 342-358. https://doi.org/10.1108/14635780710762490

Reed, R. G., Bilos, A., Wilkinson, S., \& Schulte, K. W. (2009). International comparison of sustainable rating tools. Journal of Sustainable Real Estate, 1(1), 1-22.

Reed, R. G., \& Wilkinson, S. J. (2005). The increasing importance of sustainability for building ownership. Journal of Corporate Real Estate, 7(4), 339-350. https://doi.org/10.1108/14630010510700831

RICS. (2013). RICS professional guidance, global sustainability and commercial property valuation. Royal Institution of Chartered Surveyors (RICS), London, United Kingdom. https://www.rics.org/globalassets/rics-website/media/upholding-professional-standards/sector-standards/valuation/ sustainability-and-commercial-property-valuation-2nd-edition-rics.pdf

RICS. (2015). Advancing responsible business practices in land, construction and real estate use and investment. Royal Institution of Chartered Surveyors (RICS), London, United Kingdom. https://www.rics.org/globalassets/rics-website/media/about/ responsible-business-report-exec-summary-rics-ungc.pdf

S\&P Dow Jones Indices LLC. (2019). Talking points - adding ESG transparency to real estate. https://www.spglobal.com/_assets/ documents/corporate/education-talking-points-adding-esgtransparency-to-real-estate-2-.pdf

Shan, M., \& Hwang, B. (2018). Green building rating systems: global reviews of practices and research efforts. Sustainable Cities and Society, 39, 172-180. https://doi.org/10.1016/j.scs.2018.02.034

UNEP FI. (2014). Sustainability metrics - translation and impact on property investment and management. International Environment House Chemin des Anémones, Genève Switzerland. https://www.unepfi.org/fileadmin/documents/UNEPFI_SustainabilityMetrics_Web.pdf

UNGC. (2010). An introduction to linkages between UN global compact principles and ISO 26000 core subjects. UN Global Compact Office, New York. https://www.unglobalcompact.org/library/236

UNGC. (2014). Guide to corporate sustainability - shaping a sustainable future. Two United Nations Plaza New York, US. https://www.unglobalcompact.org/library/1151

Vieira de Castro, A., Neila González, F., \& Ramírez Pacheco, G. (2014, July). Greenfield shopping centre development. The integration between environmental features, building design and investment analysis at the decision-making stage. Paper presented at the 21st Annual European Real Estate Society Conference, Bucharest, Romania.

Vierra, S. (2011). Green building standards and certification systems. Steven Winter Associates, Inc, Washington D.C.

Warren-Myers, G. (2012). Sustainable management of real estate: is it really sustainability? Journal of Sustainable Real Estate, 4(1), 177-197. 